H. А. Новікова,

д. е. н., професор, завідувач кафедри публічного управління та адміністрування,

Київський начіональний торговельно-економічний університет

ORCID ID: 0000-0001-5219-9494

K. В. Притула,

аспірант І курсу спечіальності "Публічне управління та адміністрування",

Київський начіональний торговельно-економічний університет

ORCID ID: 0000-0003-1831-9856

DOI: $10.32702 / 2306-6814.2020 .5-6.123$

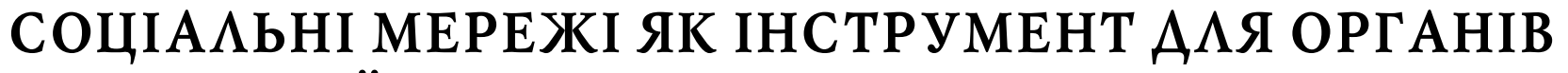

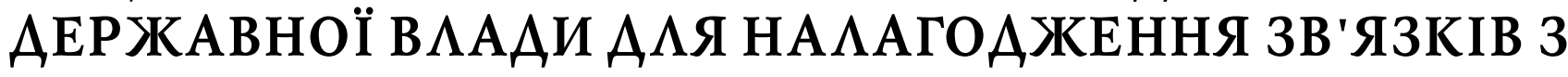 ГРОМААСЬКICТЮ
}

\author{
N. Novikova, \\ Doctor of Economic Sciences, Professor, Head of the Department of Public Administration, \\ Kyiv National University of Trade and Economics \\ K. Prytula, \\ postgraduate student of the first year of the specialty "Public Administration" \\ of Kyiv National University of Trade and Economics
}

\section{SOCIAL NETWORKS AS A TOOL FOR PUBLIC AUTHORITIES FOR ESTABLISHING PUBLIC RELATIONS}

У статтідосліджено питання ролі комунікацій в системі органів державної влади. Запропоновано визначення терміну "зв'язки з громадськістю" (PR) та обгрунтовано необхідність використання PR-інструментів в діяльності урядових інституцій. Проаналізовано актуальні нормативно-правові акти, що стосуються функціонування центральних органів виконавчої влади, що відповідають за формування інформаційної політики та цифрової трансформації. Вивчено світові тенденції розвитку мережі Інтернет та розглянуто можливість застосування соціальних мереж як одного з каналів комунікації з громадськістю. Здійснено моніторинг веб-сайтів урядових інституцій та офіційних сторінок політичних осіб у соціальних мережах. Вивчено успішні практики застосування соціальних мереж для інформування громадськості щодо розробки та запуску нової адміністративної послуги для населення. Окреслено можливі шляхи збільшення рівня довіри до державних органів та запропоновано способи вдосконалення діючих стратегічних комунікацій.

This article examines the role of communications in the public authorities' system. The authors examine the existing definitions of the term 'public relations" (PR) proposed by Ukrainian and foreign theorists and practitioners, outline the core features of this term and propose their own definition of the public relations. The world trends of Internet development and its usage in different aspects of people's life are surveyed and the possibility of using social networks as one of the channels of communication with the public is considered. It was drawn out the place and role of Internet in business and administrative performance. The latest statistics data were investigated and compared to the previous years. The authors underline the necessity of using public relations' tools in the activities of government institutions. The legal acts that entered into force in Ukraine concerning the functioning of the central executive bodies responsible for the information and digital transformation policy-making are also analyzed. The particular attention was paid to the development of strategic communications in Ukraine and the creation and functioning of the Ministry of Digital Transformation of Ukraine. The official websites of several governmental institutions and social network profiles of Ukrainian political personalities have been monitored. Successful practices of using social networks to inform the public about the development and launch of new administrative services for the population have been studied. The launch of mobile application Diia that is aimed to reduce the number of paper documents and to deliver administrative services to the citizens in a proper way was one of the subjects to analyze. The authors monitored the dynamics of upload and usage of the application in the first week of launch (February 2020). Also the possible ways of increasing the level of trust in state authorities are outlined in the article and the ways of 
improving existing strategic communications are proposed. The research on the communications in governmental institutions with the usage of modern tools is going to be continued in the further scientific publications.

Ключові слова: зВ'язки з громадськістю, комунікація, органи державної влади, Взаємодія, соціальні мережі, мобільні додатки.

Key words: public relations, communication, authorities, interaction, social networks, mobile applications.

\section{ПОСТАНОВКА ПРОБАЕМИ ТА ЇÏ ЗВ'ЯЗОК ІЗ ВАЖАИВИМИ НАУКОВИМИ ЧИ ПРАКТИЧНИМИ ЗАВААННЯМИ}

Питання урядових комунікацій завжди було контроверсійним. 3 одного боку, система державних органів вважалася закритою та консервативною у своїй комунікації "назовні", з іншого - в умовах стрімкого розвитку інформаційних технологій та побудови сучасного демократичного суспільства необхідно використовувати максимально ефективно усі наявні інструменти для налагодження діалогу із громадськістю.

Комунікація між державними органами та громадськістю стає більш динамічною та різноплановою. Громадяни хочуть отримувати інформацію за свої запити та отримувати публічні послуги швидше та якісніше. Саме тому важливо переглянути комунікаційні стратегії державних органів, додавши до них технологічну та маркетингову складові. А в тих установах, де стратегії відсутні - нарешті розробити та затвердити їх.

\section{АНААIЗ ОСТАНHIX АОСАIАЖЕНЬ І ПУБ $\Lambda$ ІКАЦІЙ}

Питання взаємодії органів влади з громадськістю досліджували відомі українські та зарубіжні вчені теоретики та практики: Алюшина Н.О., Бакуменко В.Д., Гавлін М., Грехем М., Кіслов Д.В., Колосок С.В., Королько В.Г., Куйбіда В.С, Лашкіна М.Г., Пахнін М.Л., Почепцов Г.Г., Хаджирадєва С.К. та ін. Однак все залишаються недостатньо дослідженими питання використання сучасних інформаційних технологій в публічному управлінні в умовах переосмислення ролі мас-медіа в діалозі громадськості та влади та приведення у відповідність українського законодавства до європейських стандартів інфрормаційної політики.

\section{META CTATTI}

Метою статті $€$ охарактеризувати сучасний стан взаємодії органів державної влади з громадськістю в контексті змін в інформаційному середовищі та розглянути можливість фрормування суспільної довіри шляхом використання в стратегічних комунікацій соціальних мереж та мобільних додатків.

\section{ВИК ААА ОСНОВНОГО МАТЕРІААУ}

Сьогодні важко уявити світ без використання мас-медіа та сучасних інформаційних технологій. Відповідно до результатів Глобального цифррового звіту 2019 року [2] за станом на січень 2019 року у світі налічувалося 4,388 млрд осіб, що користуються мережею Інтернет, з них 3,484 млрд осіб є активними користувачами соціальних мереж. Ці показники щороку збільшуються зі стабільною динамікою. Так, у порівнянні з 2018 роком, кількість користувачів мережі Інтернет збільшилася на 367 млн осіб, а кількість користувачів соціальних мереж зросла на 288 млн осіб. Це становить 9,1\% та 9\% відповідно. Інформаційний простір швидко та невпинно переходить в Інтернет площину, залишаючи такі "класичні" джерела інформації, як ТБ та друковані ЗМІ, у минулому. Відповідно до результатів дослідження, проведеного дослідницькою компанією Factum Group на замовлення Інтернет-асоціації України в Україні налічується 22,96 млн регулярних користувачів Інтернету, що становить близько $71 \%$ населення країни (населення без урахування АР Крим та окупованих територій, віком від 15 років) [3]. У рамках дослідження було виявлено, що станом на грудень 2019 року $47 \%$ користувачів мережі Інтернет регулярно використовують додаток інстаграм (Instagram), 41\% користуються мережею фрейсбук (Facebook) та 41\% - додатком телеграм (Telegram). Тобто майже кожний другий користувач користується соціальними мережами.

Окрім функції інфрормування, мережа Інтернет перейняла на себе левову частку комерційної складової, перетворившись у бізнес-середовище. Інтернет пропонує широкий спектр напрямків діяльності, водночас "не вимагаючи" певного територіального розташування. Продаж товарів, надання послуг та бізнес на трафіку є одними з основних комерційних діяльностей, які можна здійснювати в мережі. Підприємці мають змогу заощадити кошти на фрізичному утриманні приміщення та продукції для демонстрації споживачу, адже наявність детального опису товару чи послуги, їх зображення та, що найголовніше, відгуки інших покупців, роблять свою справу: зменшують витрати на процес продажу та створюють рекламу, якає досить витратним, але дуже необхідним етапом маркетингу.

Державні органи, окрім функцій фрормування та реалізації політики, є надавачами публічних послуг для населення. Головна відмінність між бізнесом та державними органами в даному аспекті полягає в тому, що адміністративні послуги не достатньо "рекламуються" та не завжди забезпечується належний доступ до них. Саме Інтернет може стати тим інструментом, що допоможе усунути "бар'єри" між владою та громадськістю.

Специфріка діяльності державних органів полягаєу тому, що виконується величезний обсяг роботи (аналітичної, нормопроектувальної, перформативної), але громадськість не знає і третини результатів, які досягаються під час формування та реалізації політики. Схожа ситуація із переліком адміністративних послуг, які надаються кожним окремим органом влади. Саме для інформування населення про досягнення та виклики, можливості для суспільства, а також побудови діалогу між громадянином "платником податків" та державою "послугонадавачем" і необхідно встановити та постійно підтримувати зв'язки з громадськістю.

Існує ціла низка визначень поняття "зв'язки з громадськістю", що в світі більше відомо як "паблік рілейшнз". Зокрема:

"паблік рілейшнз - це розвинута науково-прикладна дисципліна, і повсякденна практична діяльність як 
важлива складова репутаційного менеджменту будьякої організації" [5, с. 22].

"PR - це навмисне, плановане і тривале зусилля, спрямоване на досягнення іпідтримку взаємного розуміння між організацією та громадськістю" (Британський Інститут PR).

"Зв'язки з громадськістю - формування системи комунікацій соціального суб'єкта з громадськістю, що забезпечує оптимізацію соціальних взаємодій зі значимими для нього сегментами середовища" (М. А. Шишкіна) [10].

"Зв'язки із громадськістю - це комунікативна дисципліна, спрямована на організацію комунікативного простору в сприятливому режимі для об'єкта зв'язків із громадськістю та покликана управляти позитивним іміджем фрірми або людини" (Г. Почепцов) [7, с. 16].

Скотт М. Катліп, Ален Г. Центер і Глен М. Брум у своїй книзі "Ефективні зв'язки з громадськістю" наводять таке визначення: "Зв'язки з громадськістює таким різновидом управлінської діяльності, яка відповідає за визначення, встановлення і підтримку взаємовигідних взаємин між повною організацією і тими численними групами суспільства, від яких залежить успіх або невдача діяльності даної фрірми" [1].

"Зв'язки із громадськістю - це управління суспільним сприйняттям істратегічними взаєминами між певною організацією і всіма (як внутрішніми, так і зовнішніми) колами, зацікавленими в ії̈ діяльності, яке здійснюється за допомогою комунікації" (Визначення Південно-Африканського інституту із вивчення зв'язків із громадськістю).

"Зв'язки із громадськістю - це систематична і послідовна управлінська діяльність, за допомогою якої приватні і громадські організації вирішують завдання зі встановлення розуміння, позитивного ставлення і підтримки в тих громадських колах, в яких вони здійснюють (або планують здійснювати) свою діяльність" [8].

Англійський вчений Сем Блек [4] дає своє трактування поняття PR: "плановані, тривалі зусилля, спрямовані на створення та підтримку доброзичливих відносин і взаєморозуміння між організацією та її громадськістю".

Отже, зв'язки з громадськістю в державному управлінні - це запланована, тривала та комплексна діяльність у сорері комунікацій, спрямована на встановлення та підтримки постійної взаємодії з суспільством, формування позитивного іміджу інституції та зміцнення рівня довіри до органів влади.

Ключовим моментом зв'язків з громадськістю $€$ саме досягнення розуміння та взаємодії. Взаємодія ж може бути досягнута виключно за умови фрункціонування дво- або багатосторонньої комунікації.

Відомий теоретик у сорері комунікацій професор Джон Марстон визначає 4 основні етапи зв' язків з громадськістю - RACE, де R - research (аналіз, дослідження), A - action (дія), C - communication (комунікація) та $\mathrm{E}$ - evaluation (оцінка).

Кожен з цих етапів $є$ важливим елементом побудови комунікації. В умовах комунікацій органів державної влади доцільно виокремити ще два етапи: формування стратегії вирішення питання та зворотній зв'язок, результати якого стануть підгрунтям для оцінки ефективності діяльності органу (рис. 1).

Використання паблік рілейшнз в урядовій діяльності $\epsilon$ ефективним способом просування місії органу за допомогою менших витрат. Наприклад, інфрормаційні кам-

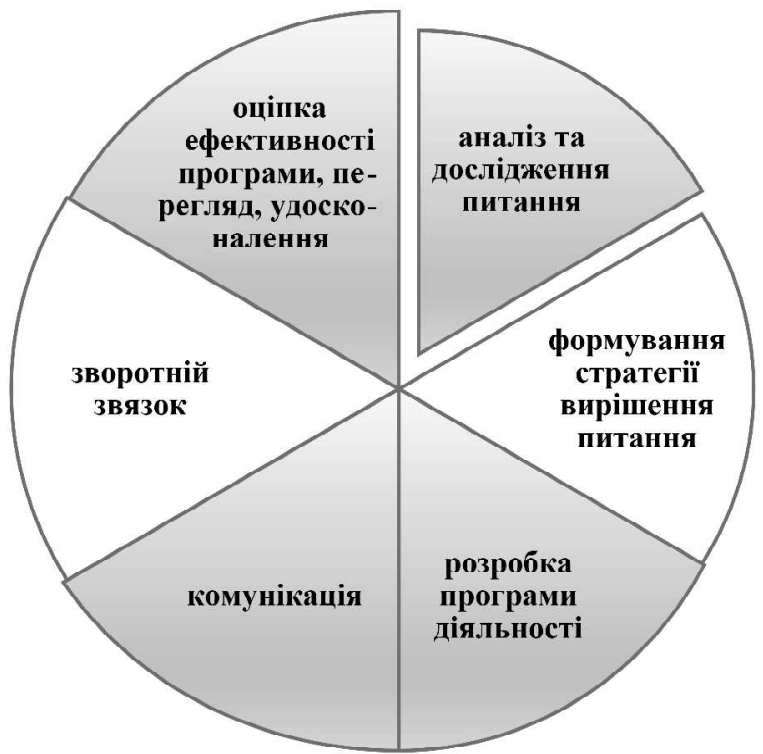

Рис. 1. Цикл функціонування зв'язків
з громадськістю

панії з надання публічних послуг можуть виступати в ролі інструменту впливу на поведінку населення, просування рішень, необхідних для досягнення цілей демократичного суспільства.

Питання побудови ефективної комунікації для державних органів України стало актуальним після Революції Гідності. Представники державної владичітко усвідомили, що без конструктивного діалогу із суспільством довіра до органів державної влади не буде відновлена. Тому саме 3 2014 року почався процес переформатування класичних прес-служб органів та установ у комунікаційні центри. Одним із перших незалежних прогресивних центрів став Український кризовий медіа-центр (УКМЦ), що був заснований у березні 2014 року. Він не підпорядковується жодному ЦОВВ, оскільки його засновником $є$ громадське об'єднання. Метою УКМЦ було надання об'єктивної інфрормації про події в Україні, виклики та загрози національній безпеці, зокрема у військовій, політичній, економічній, енергетичній та гуманітарній сорерах. УКМЦ став майданчиком для дискусій та оперативним центром останніх новин. В умовах анексії Криму та військової агресії на Донбасі це був потужний інструмент для поширення інорормації серед населення України та для закордонних партнерів.

Питання побудови інформаційної політики загалом та налагодження комунікації було окреслено 14 січня 2015 року, коли Кабінет Міністрів України ухвалив постанову "Питання діяльності Міністерства інформаційної політики України", відповідно до якої було створено Міністерство інфрормаційної політики України як окремий центральний орган виконавчої влади. Це рішення стало початком формування нових інформаційнокомунікаційних цілей для урядових інституцій.

Паралельно з урядовим процесом до зміни підходів у побудові комунікації органів влади та переглядом обов'язків і компетенцій "екс-прес-центрів", що мали перетворитися у "стратком-центри" долучилися, зокрема, Адміністрація Президента України, Апарат Верховної Ради України та органи судової влади,

У діяльності комунікаційних служб були переглянуті та зміщені акценти. Ключовим моментом був перегляд 
напрацьованих практик та відхід від схеми "анонс прес-реліз - звіт". В основі діяльності комунікаційних підрозділів мала стати комунікаційна стратегія.

Комунікації у державних структурах повинні сприйматися як обов'язкова складовапланування різнихвидів діяльності та прийняття рішень. Ефективну комунікаційну стратегію варто розглядати не лише як додаткову місію органу, ай як важливу публічну послугу, на якує стійкий попит.

Сьогодні вже не достатньо для установи мати відділ розгляду звернень громадян, телефон гарячої лінії та офріційний веб-сайт у мережі Інтернет. Значна кількість урядових інституцій вже перенесли частину своєї комунікації в площину соціальних мереж. Однак далеко не всі установи ще змінили фрормат інформування населення про свої досягнення та завдання.

Наразі ще триває процес переходу органів державної влади від класичних "усталених" завдань для прессекретарів щодо номінального інфрормування населення до залучення фахівців з комунікацій до побудови якісного діалогу між органом влади та громадськістю.

Особа чи команда, яка має відповідати за зв'язки з громадськістю виконує досить комплексну роль. Для реалізації ефективної комунікації необхідні знання не тільки журналістики, фрілології чи державного управління, а й компетенції соціолога, психолога та маркетолога для чіткого усвідомлення, які "маячки" в інформації зачеплять певну цільову аудиторію. Необхідно враховувати особливості цільової аудиторії, для якої фрормується ключове повідомлення. В залежності від ії специфріки, фрормат одногой того ж повідомлення може разюче відрізнятися.

Найтиповішою помилкоюпід час публікації інфрормації в соціальній мережі $є$ абсолютне копіювання тексту пресрелізу чи уривку зі звіту про діяльність органу. Такий фрормат тексту не буде цікавим для пересічного читача та не виконає заплановане охоплення аудиторії. Кілька поспіль опублікованих"канцелярських" повідомлень можуть ссрормувати в аудиторії враження, що уся інфрормація від даного каналу (інтернет-сторінки, профрілючи блогу) не несе суспільного інтересу та користі, і як наслідок, навіть якщо буде опублікована цікава та важлива інформація, виникає ризик, що вона буде просто "прогорнута" в новинній стрічці.

У контексті процесу "твіттерізації" медіа, найбільше охоплення аудиторії мають саме короткі публікації, що супроводжуються яскравим зображенням чи гучні заголовки або відеоролики тривалістю 3-5 хвилин.

Після проведення президентських та дострокових парламентських виборів 2019 року до посилення інформаційної політики додався ще один пріоритет - цифрова грамотність та залученість населення України. 18 вересня 2019 року Кабінет Міністрів України прийняв постанову про створення Міністерства цифрової трансорормації України. Цей центральний орган визначений відповідальним за фрормування та реалізацію державної політики у сорері цифровізації, цифрової економіки, цифрових інновацій, електронного урядування та електронної демократії, розвитку інформаційного суспільства [6].

Таким чином, діяльність органів державної влади поступово переносить частину своїх функцій в Інтернет-площину. Міністр цифрової трансформації М. Федоров у своєму телеграм-каналі нещодавно зазначив, що "хоче кардинально змінити підхід до комунікації державних органів. Традиційне поняття "прес-служби" має припинити існува- ти. Формування "позитивного образу політика/органу", - повинно перестати бути метою. Основне завдання комунікації в цей історичний період - пояснити максимальній кількості людей - куди ми рухаємося, на що спрямовані наші реформи, навчитися заміряти проміжні результати, отримувати зворотний зв'язок, чути "клієнтів" (для кого робиться реформа), покращувати процеси" [9].

Одним із перших рішень новоствореного міністерства було розроблення та запуск зручного сервісного мобільного додатку "Дія". Цей додаток має об'єднати в собі усі послуги, які надаються державою громадянам та бізнесу.

Головною відмінністю даної урядової ініціативи $є$ те, що інформування населення про розробку сервісу почалося майже одразу з моменту прийняття рішення про його розробку. Головним каналом інформування стали мережа фейсбук та телеграм-канал Міністра М. Федорова. Кожен етап розробки додатку висвітлювався коротко та доступно. Ключові повідомлення формулювалися простою мовою, без використання складної термінології та довгих речень. Окрему увагу приділяли фрінансовому аспекту - пояснювали скільки та на якому етапі держава заощаджуватиме за допомогою даного сервісу. Такий підхід $є$ дуже вдалим з точки зору оперування фінансовими показниками та демонстрацією "перемоги", що завжди викликало суспільний інтерес.

Наприклад, "за 4 місяці роботи нашого міністерства з нуля, за підтримки профільних міністрів ми заощадили бюджету України щонайменше 1380000000 грн" — таке коротке інформування про зупинення IT-закупівель менш ніж за добу отримало охоплення більше 10 тис. читачів.

6 лютого 2020 року додаток було презентовано та запущено. Вже менш ніж за добу Міністр проінфрормував, що додаток успішно завантажили та авторизували більш ніж 310 тис. користувачів, за дві доби цей показник сягнув 800 тис. користувачів, а за чотири доби відбулося 1047403 завантаження (рис. 2).

Таке поширення інформації про сервіс стало можливим саме завдяки активному використанні інструменту соціальних мереж для формування стійкого суспільного інтересу до сервісу. Відносно недавнє утворення Міністерства, абсолютно новий підхід до комунікацій 3 громадськістю дали свої позитивні результати - населення позитивно сприймає ініціативи органу та схильні більше довіряти даному органу, аніж іншим державним установам, що мають більш традиційний підхід до взаємодії з громадськістю.

\section{ВИСНОВКИ ТА ПЕРСПЕКТИВИ ПОАА}

Враховуючи надшвидку динаміку розвитку інформаційних технологій у світі та Україні зокрема, органи державної влади мають переглянути свої ключові принципи взаємодії з громадськістю. За результатами проведеного аналізу для цієї статті виокремимо такі висновки-твердження:

- українські державні комунікації є недостатньо розвиненими та не відповідають сучасним викликам;

- значна частина державних органів не має стратегічних комунікацій, а ті, що мають, - не завжди використовують їх в повному обсязі та у відповідній формі;

- складне, "канцелярське" формулювання ключових повідомлень щодо діяльності державних органів не 
вирішує проблему нерозуміння державної політики українським суспільством;

- успішні рішення та рефрорми слабо комунікуються і не підвищують авторитет влади в очах громадськості.

Для вирішення зазначених проблем державним органам варто переглянути основні комунікаційні підходи, визначити пріоритетні напрямки інформування суспільства. Щодо організаційного забезпечення, то державним органам варто залучити до управлінь, що відповідають за зв'язки з громадськістю, фрахівців з питань комунікації, включити до стратегічних комунікаційних планів моніторинг суспільних інтересів у сорері, яку регулює державний орган, та залучити як один з каналів комунікації соціальні мережі. Вивчення успішних практик українських та зарубіжних державних комунікацій в мережі Інтернет можуть стати методичною основою для формування "social media communication plan". Адже соціальні мережі на сьогодні $\epsilon$ потужним та поки фрінансово не затратним джерелом прямого контакту з великою кількістю громадян одночасно. Питання порушене у публікації потребує більш детального та комплексного дослідження та має бути відображеним у таких публікаціях.

\section{Література:}

1. Cutlip S. M., Center A. H., Broom F. M. Effective public relations 7-th edition - Englewood Cliffs, N. J. Prentice Hall, 1994 - P. 1-8.

2. The Global State of Digital in 2019 Report [Електронний ресурс] // Hootsuite. - 2019. - Режим доступу до ресурсу: https://hootsuite.com/pages/digital-in2019

3. Дані досліджень інтернет-аудиторії України [Електронний ресурс] // Інтернет Асоціація України (ІнАУ). - 2020. - Режим доступу: https://inau.ua/ proekty/doslidzhennya-internet-audytoriyi.

4. Зв'язки з громадськістю: технології прагматичної комунікації: навч. посіб. / Л.Д. Климанська; М-во освіти і науки України, Нац. ун-т "Львів. Політехніка". - Л.: Вид-во Львів. Політехніки, 2014. - 164 с.

5. Королько В.Г., Некрасова О.В. Зв'язки з громадськістю. Наукові основи, методика, практика: підр. Для студентів вищих навчальних закладів / 3-те вид., доповн. І переробл. - К.: Вид. дім. "Києво-Могилянська академія", 2009. - 831 с.

6. Постанова Кабінету Міністрів України "Питання Міністерства цифррової трансфрормації" від 18 вересня 2019 р. № 856 [Електронний ресурс]. — 2019. - Режим доступу до ресурсу: https://zakon.rada.gov.ua/ laws /show $/ 856-2019-\%$ D0\%BF

7. Почепцов Г.Г. Паблік рилейшнз: навч. посіб. / Г.Г. Почепцов. - К.: Знання, 2006. - 327 с.

8. Руденко О.І. Поняття "політичні зв'язки з громадськістю" в наукових дискусіях, тематика: політичні проблеми міжнародних систем і глобального розвитку // Освіта регіону. Сер.: Політологія. Психологія. Комунікації. - 2011. - № 2. - С. 107-110.
Завантаження додатку "Дія"

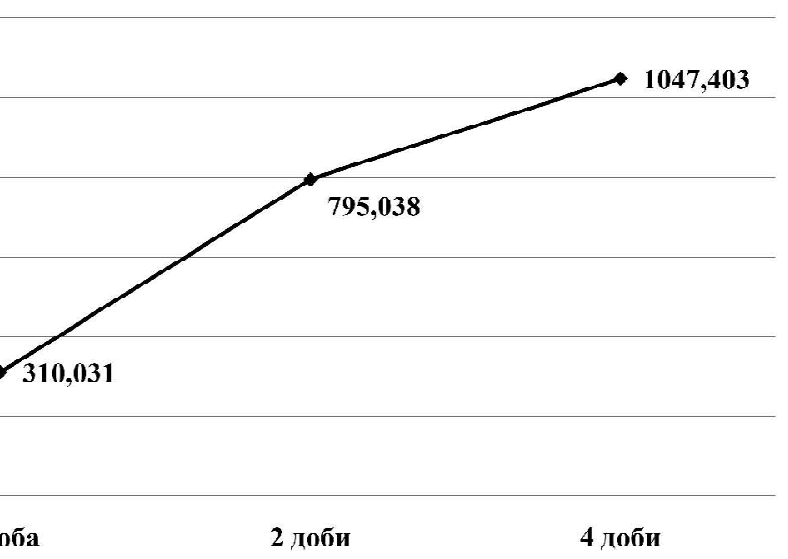

2. Динаміка завантажень додатку "Дія"

9. Телеграм канал Міністра цифрової трансформації М.Федорова [Електронний ресурс]. - Режим доступу до ресурсу: https://t.me/zedigital

10. Шишкина М.А. Паблик рилейшнз в системе социального управления / М.А. Шишкина. - СПб: Русич, 2002. - 441 с. - (Паллада-медиа).

References:

1. Cutlip, S.M. Center, A.H. and Broom, F.M. (1994), Effective public relations, 7-th edition, Prentice Hall, Englewood Cliffs, N. J., USA, pp. 1-8.

2. Hootsuite (2019), "The Global State of Digital in 2019 Report", available at: https://hootsuite.com/pages / digital-in-2019 (Accessed 25 Feb 2020).

3. InAU (2020), "Research data of Internet audience of Ukraine", available at: https://inau.ua/proekty/ doslidzhennya-internet-audytoriyi (Accessed 25 Feb 2020).

4. Klymans'ka, L.D. (2014), Zv'iazky z hromads'kistiu: tekhnolohii prahmatychnoi komunikatsii [Public relations: pragmatic communication technologies], M-vo osvity $i$ nauky Ukrainy, Nats. Un-t "L'viv. Politekhnika". Vyd-vo L'viv. Politekhniky, L'viv, Ukraine.

5. Korol'ko, V.H. and Nekrasova, O.V. (2009), Zv'iazky z hromads'kistiu. Naukovi osnovy, metodyka, praktyka [Public relations. Scientific bases, methodology, practice], Vyd. dim. "Kyievo-Mohylians'ka akademiia", Kyiv, Ukraine.

6 . Cabinet of Ministers of Ukraine (2019), Resolution "Questions from the Ministry of Digital Transformation", available at: https://zakon.rada.gov.ua/laws/show/ 856-2019-\% D0\%BF (Accessed 25 Feb 2020).

7. Pocheptsov, H.H. (2006), Pablik rylejshnz [Public Relations], Znannia, Kyiv, Ukraine.

8. Rudenko, O.I. (2011), "The concept of "political public relations" in scientific discussions, topics: political problems of international systems and global development", Osvita rehionu. Ser.: Politolohiia. Psykholohiia. Komunikatsii, vol. 2, pp. 107-110.

9. Telegram channel of the Minister of Digital Transformation M.Fedorov (2020), available at: https:// t.me/zedigital (Accessed 25 Feb 2020).

10. Shyshkyna, M.A. (2002), Pablyk rylejshnz v systeme sotsyal'noho upravlenyia [Public relations in the social management system], Rusych, St.Petersburg, Russia.

Стаття надійила до редакиї 02.03.2020 p. 